\title{
A Freshwater Hydrobiid, cf. the Squat Duskysnail, Lyogyrus granum (Mollusca), Widespread in the Hampton Marsh, New Brunswick
}

\author{
Donald F. McAlpine ${ }^{1}$, Rachel H. Maillet ${ }^{1}$, Andrew J. Albert ${ }^{1}$, Laura M. Crossman ${ }^{1}$, Rebecca \\ R. SMITH ${ }^{1}$, and ANDRÉ L. MARTEL ${ }^{2}$
}

${ }^{1}$ New Brunswick Museum, 277 Douglas Avenue, Saint John, New Brunswick E2K 1E5 Canada

${ }^{2}$ Canadian Museum of Nature, P.O. Box 3443, Station D, Ottawa, Ontario K1P 6P4 Canada

McAlpine, Donald F., Rachel H. Maillet, Andrew J. Albert, Laura M. Crossman, Rebecca R. Smith, and André Martel. 2007. A freshwater hydrobiid, cf. the Squat Duskysnail, Lyogyrus granum (Mollusca), widespread in the Hampton Marsh, New Brunswick. Canadian Field-Naturalist 121(1): 92-94.

In Canada, the Squat Duskysnail, Lyogyrus granum, is an apparently rare freshwater hydrobiid. We document putative $L$. granum to be widespread throughout the Hampton Marsh, New Brunswick, with densities sometimes exceeding $150 \mathrm{snails} / \mathrm{m}^{2}$ on substrates ranging from vegetated organic detritus over mud, to sparsely-vegetated cobble/sand lakeshore. That our identification of L. granum from Hampton Marsh remains tentative, in spite of large samples, emphasizes the need for detailed taxonomic study of any putative L. granum populations in Canada. Such study will be necessary before the true conservation status can be determined for this and any related taxa, as yet unrecognized in Canadian material.

Key Words: Squat Duskysnail, Lyogyrus granum, Hydrobiidae, conservation status, New Brunswick.

Of the two species of freshwater hydrobiid snails recorded in Maritime Canada (Clarke 1981), the Ordinary Spire Snail, Amnicola limosa, and the Squat Duskysnail, Lyogyrus granum, the latter is very poorly known. In part, this is due to difficulties in identification; Smith (1991) notes that in Massachusetts $L$. granum and $L$. pupoidea will rarely be confidently distinguished from each other and Jokinen (1992) has reported sexual dimorphism within the genus that is poorly understood.

In Canada, $L$. granum has been reported from only two locations in south-central New Brunswick (Jemseg and Baker Brook) and 11 sites in Nova Scotia (COSEWIC 2003*). COSEWIC (2003*) suggested that L. granum is rare in Canada and that the only known Canadian populations in New Brunswick and Nova Scotia should be considered nationally significant. Nonetheless, a paucity of information on this species has led to a designation of Data Deficient by the Committee on the Status of Endangered Wildlife in Canada (COSEWIC). Here we document a $L$. granum-like hydrobiid to be abundant and widespread in the Hampton Marsh, New Brunswick.

Considered one of the largest and most diverse freshwater marshes in the Saint John River floodplain, the 2000 hectare Hampton Marsh $\left(45^{\circ} 33^{\prime} \mathrm{N}, 65^{\circ} 50^{\prime} \mathrm{W}\right)$ consists of a series of eutrophic oxbows, tributaries and backwaters of the Kennebecasis and Hammond Rivers. The marsh has repeatedly been identified as a site of ecological importance within the province (Stocek 1984*; Dionne et al. 1988; Austin-Smith 1994*) and is currently designated as a wetland of significance by the Wetlands and Coastal Habitat Program of the New Brunswick Department of Natural Resources and Energy. Although about $40 \%$ of the land adjacent to the marsh remains forested (Austin-Smith 1994*), shoreline development, sedimentation, eutrophication, and pesticide introduction from upstream agricultural areas are issues of concern. The marsh is located largely within the municipal boundaries of Hampton and Quispamsis, two of the fastest growing urban areas in New Brunswick, and the Local Service District of Nauwigewauk (Austin-Smith 1994*).

Putative L. granum were discovered in the Hampton Marsh during the course of ongoing mollusc surveys on the lower Saint John River and tributaries (Sabine et al. 2004; McAlpine et al. 2005). Data reported here were collected from 20 June to 22 August 2005 from 25 survey sites scattered across the marsh. Survey sites had been selected based on study of aerial photos, topographic and nautical maps, and field inspection, to represent a variety of habitat types (i.e., lakeshore, river channel, backwaters, oxbows) within the marsh complex. Molluscs were collected using a combination of techniques that included SCUBA, snorkeling, dip netting, and sieving bottom sediments; voucher material of all mollusc species reported here has been placed in the New Brunswick Museum mollusc collection. To provide abundance estimates for putative L. granum in contrasting habitats within the marsh, $150.25-\mathrm{m}^{2}$ random quadrats were also sampled in $\sim 1 \mathrm{~m}$ of water in August at three of the sites. Only live snails were tabulated in quadrats following the complete removal, sieving, and hand-sorting of the top $5 \mathrm{~cm}$ of sediment along with all aquatic vegetation. Hampton Marsh specimens of Lyogyrus were identified largely on the basis of the structure of the verge in fresh material as described and illustrated in Smith (1991) and Jokinen (1992), but reference was also made to shell and opercular morphology as noted by these authors, and by Clarke (1981). As well, comparison was made with Atlantic Canadian material in the collection of the Canadian Museum of Nature. Although $L$. pupoidea has not been recorded in Canada, our extensive series of specimens agree with Smith (1991), in that intermediates and extremes showing external morpholog- 
TABLE 1. Densities of putative Lyogyrus granum in contrasting habitats in the Hampton Marsh, New Brunswick.

\begin{tabular}{|c|c|c|c|c|}
\hline GPS & Habitat & Mean $\pm \operatorname{sd}\left(/ \mathrm{m}^{2}\right)$ & Range $\left(/ \mathrm{m}^{2}\right)$ & Associated molluscs ${ }^{1}$ \\
\hline $\begin{array}{l}\mathrm{N} 45^{\circ} 30.025^{\prime} \\
\mathrm{W} 65^{\circ} 52.50^{\prime}\end{array}$ & rocky lakeshore, & $96.8 \pm 52.6$ & $48-184$ & $\begin{array}{l}\mathrm{Ai}, \mathrm{Al}, \mathrm{Cd}, \mathrm{Ec}, \mathrm{Gd}, \mathrm{Ha}, \mathrm{Lr}, \mathrm{Pc}, \\
\mathrm{Ph}, \mathrm{Sc}, \mathrm{Se}, \mathrm{Vt},\end{array}$ \\
\hline $\begin{array}{l}\mathrm{N} 45^{\circ} 31.358^{\prime} \\
\mathrm{W} 65^{\circ} 52.867^{\prime}\end{array}$ & $\begin{array}{l}\text { clearwater } \\
\text { Ceratophyllum marsh }\end{array}$ & $76.0 \pm 63.9$ & $4-160$ & $\begin{array}{l}\mathrm{Ai}, \mathrm{Al}, \mathrm{Ec}, \mathrm{Gd}, \mathrm{Ha}, \mathrm{Pa}, \mathrm{Ph}, \\
\mathrm{Se}, \mathrm{Ss}, \mathrm{Vs}, \mathrm{Vt}\end{array}$ \\
\hline $\begin{array}{l}\mathrm{N} 45^{\circ} 31.856^{\prime} \\
\mathrm{W} 65^{\circ} 51.297^{\prime}\end{array}$ & $\begin{array}{l}\text { murky } \\
\text { backwater channel }\end{array}$ & $17.6 \pm 12.5$ & $8-20$ & $\begin{array}{l}\mathrm{Al}, \mathrm{Cd}, \mathrm{Ec}, \mathrm{Fp}, \mathrm{Gd}, \mathrm{Pc}, \mathrm{Ph}, \mathrm{Se} \text {, } \\
\text { Ss, Vs, Vt }\end{array}$ \\
\hline
\end{tabular}

${ }^{1} \mathrm{Ai}=$ Anodonta implicata, $\mathrm{Al}=$ Amnicola limosa, $\mathrm{Cd}=$ Campeloma decisum, Ec=Elliptio complanata, $\mathrm{Fp}=$ Ferrissia parallela, $\mathrm{Gd}=$ Gyraulus deflectus, $\mathrm{Ha}=$ Helisoma anceps, $\mathrm{Pa}=$ Planorbella campanulata, $\mathrm{Lr}=$ Lampsilis radiata, $\mathrm{Pc}=$ Pyganodon cataracta, $\mathrm{Ph}=$ Physa heterostropha, $\mathrm{Ss}=$ Sphaeriidae sp., Sc=Stagnicola catascopium, $\mathrm{Se}=$ Stagnicola elodes, Vs=Valvata sincera, $\mathrm{Vt}=$ Valvata tricarinata

ical features of $L$. pupoidea are present. COSEWIC $\left(2003^{*}\right)$ notes the possibility of $L$. pupoidea, as well as closely related $L$. browni, overlapping the Canadian range for $L$. granum. Clearly there is a need for detailed taxonomic study of any putative $L$. granum populations in Canada before the true distribution and conservation status of this and related species in the country can be determined.

Putative $L$. granum are widespread throughout the Hampton Marsh, although they were noticeably absent from sites in the river channel, where currents of $0.1-0.3 \mathrm{~m} / \mathrm{sec}$ were recorded, and in the lowest portion of the marsh where there is periodic intrusion of brackish water. Discounting two sites where brackish water clearly intrudes on occasion, we recorded $L$. granum at 17 of the 22 survey sites remaining. The limited habitat data available for Lyogyrus indicates that this species is generally found on organic debris and vegetation in standing water (Clarke 1981; Smith 1987*; Jokinen 1983). Currents at sites where we recorded Lyogyrus did not exceed $0.1 \mathrm{~m} / \mathrm{sec}$. COSEWIC (2003*) reports $L$. granum densities of up to $400 / \mathrm{m}^{2}$; densities in the Hampton Marsh were lower but sometimes exceeded $150 / \mathrm{m}^{2}$ (Table 1). We found the highest densities along an open, sparsely-vegetated cobble/sand lake shore on rocks and on the living shells of the unionids Elliptio complanata, Anodonta implicata and Lampsilis radiata. Lyogyrus granum was also abundant in clear water on submersed vegetation where Ceratophyllum demersum dominated (lakeshore vs clear water; Mann-Whitney $U=15, P>0.05$ ) but significantly less abundant in a murky vegetation-clogged backwater channel characterized by Vallisneria americana and Potamogeton perfoliatus than on the rocky lake shore (lake shore vs backwater; Mann-Whitney $U=25, P<0.05$ ) (Table 1). Both of the more heavily vegetated sites were characterized by deep bottom layers of organic detritus over mud.

COSEWIC $\left(2003^{*}\right)$ suggests that the few sites from which the species has been recorded in Canada indicate either that $L$. granum is a habitat specialist, that human impacts are reducing the availability of suitable habitat, that $L$. granum is a truly rare species, or some combination of these factors. That the rarity of this species may only be apparent, due to a lack of collecting, is not mentioned. Jokinen $(1983,1992)$ found this snail to be uncommon in Connecticut, and both Smith (1987*) and Jokinen (1992) found the species to be rare in Massachusetts and New York, respectively. While $L$. granum may indeed prove to be naturally rare, this species is small and easily overlooked and there have been few detailed surveys of the freshwater gastropods of Atlantic Canada. That L. granum has been recorded from 11 widely distributed sites across Nova Scotia also suggests that further field investigation may show this species, in association with related taxa as yet unrecognized in Canada, to be more prevalent in the region than current records indicate.

\section{Acknowledgments}

Financial support for this project was provided through grants to DFM from the Community-University Research Alliance program of the Social Sciences and Humanities Research Council of Canada, The Salamander Foundation, the New Brunswick Wildlife Trust Fund, and the Province of New Brunswick Summer Mentorship Program for Female Students. Laurie Mills and James Wilson of the Hampton Area Environmental Group assisted with field arrangements while Archie and Connie Downey were unfailingly gracious in providing access to the marsh through their property and providing use of a wharf and other amenities; Gart Bishop and Geoffry McBriarty assisted with the field sampling of molluscs.

Documents Cited (marked * in text)

Austin-Smith, P. 1994. Hampton-Kennebecasis Marsh Complex - Status Report. Town of Hampton, New Brunswick, 99 pages.

COSEWIC. 2003. Assessment and update status report on the Squat Duskysnail, Lyogyrus granum, in Canada. Committee on the Status of Endangered Wildlife in Canada. Ottawa. [unpublished report]. vi +27 pages.

Smith, D. G. 1987. Keys to the freshwater invertebrates of Massachusetts, Number 2. Mollusca Mesogastropoda (operculate snails). Massachusetts Department of Environmental Quality Engineering, Division of Water Pollution Control (Westborough). 34 pages. 
Stocek, R. 1984. Environmentally significant areas in the Saint John Planning Region. Environmental Services Branch, Environment New Brunswick, Fredericton, New Brunswick. 116 pages.

\section{Literature Cited}

Clarke, A. H. 1981. The freshwater molluscs of Canada. National Museum of Natural Sciences, National Museums of Canada, Ottawa. 446 pages.

Dionne, L. A., D. M. Farmer, and M. C. Young. (Compilers). 1988. Critical natural areas in New Brunswick. New Horizons Critical Natural Areas Committee, Fredericton, New Brunswick. 313 pages.

Jokinen, E. H. 1983. The freshwater snails of Connecticut. State Geological and Natural History Survey of Connecticut. Department of Environmental Protection Bulletin 109: $1-83$.
Jokinen, E. H. 1992. The freshwater snails (Mollusca: Gastropoda) of New York State. New York State Museum Bulletin 482.112 pages.

McAlpine, D. F., D. L. Bateman, and C. A. Davis. 2005. Spurwinkia salsa (Pilsbry 1905) (Gastropoda: Hydrobiidae) in the Kennebecasis River estuary, New Brunswick: A brackish water snail new to Canada. Journal of Conchology 38: 602-604.

Sabine, D. L., S. Makepeace, and D. F. McAlpine. 2004 The Yellow lampmussel (Lampsilis cariosa) in New Brunswick: A population of significant conservation value. Northeastern Naturalist 11: 407-420.

Smith, D. G. 1991. Keys to the freshwater macroinvertebrates of Massachusetts. Department of Zoology, University of Massachusetts, Amherst, Massachusetts. 236 pages.

Received 27 February 2006

Accepted 5 November 2007

\title{
Northern Range Extension of the Pygmy Shrew, Sorex hoyi, in the Yukon
}

\author{
Thomas S. Jung ${ }^{1}$, Troy D. Pretzlaw ${ }^{2}$, and David W. Nagorsen ${ }^{3}$
}

${ }^{1}$ Fish and Wildlife Branch, Yukon Department of Environment, Box 2703, Whitehorse, Yukon Y1A 2C6 Canada; e-mail: thomas.jung@gov.yk.ca

${ }^{2}$ Department of Natural Resource Sciences, McGill University, 21111 Lakeshore Blvd., Montreal, Quebec H9X 3V9 Canada

${ }^{3}$ Mammalia Biological Consulting, 4268 Mechosin Road, Victoria, British Columbia V9C 3Z4 Canada

Jung, Thomas S., Troy D. Pretzlaw, and David W. Nagorsen. 2007. Northern range extension of the Pygmy Shrew, Sorex hoyi, in the Yukon. Canadian Field-Naturalist 121(1): 94-95.

A Pygmy Shrew, Sorex hoyi, was captured in a pitfall trap on the Blackstone River $\left(65^{\circ} 04.6^{\prime} \mathrm{N}, 138^{\circ} 10.8^{\prime} \mathrm{W}\right)$ in central Yukon. This represents a northern range extension of about $110 \mathrm{~km}$ for $S$. hoyi in the Yukon.

Key Words: Distribution, Pygmy Shrew, Sorex hoyi, Yukon.

Shrews, Sorex, have been undersampled in northwestern North America because they are often not the focus of surveys (Jarrell 1986; Nagorsen 1996) and they are not readily captured in traps designed for small rodents (Nagorsen 1996). As such, our knowledge of the distributions of shrews in northwestern North America (i.e., Alaska, Yukon, northern British Columbia, western Northwest Territories) is limited. In recent years, however, directed surveys of shrews in this vast region have resulted in discovery of a new species, the Alaskan Tiny Shrew, Sorex yukonicus (Dokuchaev 1997), and range extensions for a number of species (e.g., American Water Shrew, S. palustris, Jarrell 1986; Cook et al. 1997; Tundra Shrew, S. tundrensis, Nagorsen and Jones 1981; Alaskan Tiny Shrew, S. yukonicus, and Pygmy Shrew, S. hoyi, Peirce and Peirce 2000). Nevertheless, much work is needed to better understand the distributions of shrews in northwestern North America. Herein, we describe a northern range extension for $S$. hoyi in the Yukon.

During an extensive survey of the small mammal fauna along the Dempster Highway in central Yukon, a Pygmy Shrew was captured on 12 July 2005, $2 \mathrm{~km}$ west of the Blackstone River $\left(65^{\circ} 04.6^{\prime} \mathrm{N}, 138^{\circ} 10.8^{\prime} \mathrm{W}\right)$, $129 \mathrm{~km}$ northeast of Dawson City. The shrew was cap- tured in an unbaited pitfall trap installed flush with the substrate. Pitfall traps have been found to be particularly effective for Pygmy Shrews (Prince 1941). No other shrews were captured at this site. The specimen was identified using dental characteristics and keys in Nagorsen (2002) and van Zyll de Jong (1983). The specimen (Field ID: DEMP-0015) is held by the Yukon Department of Environment, but will be deposited at the Museum of Southwestern Biology.

Our record represents a northern range extension of approximately $110 \mathrm{~km}$ for $S$. hoyi in the Yukon. Youngman (1975) mapped the hypothetical range as being as far north as the Old Crow Flats (approximately $\left.68^{\circ} \mathrm{N}\right)$. Prior to our capture, however, the northernmost specimen records of $S$. hoyi in the Yukon were from $22 \mathrm{~km}$ east of Dawson City (Youngman 1975; van Zyll de Jong 1983) and the abandoned village of Fortymile $\left(64^{\circ} 25^{\prime} \mathrm{N}, 140^{\circ} 32^{\prime} \mathrm{W}\right), 67 \mathrm{~km}$ northwest of Dawson City (B. G. Slough and T. S. Jung, unpublished data).

This Yukon range extension of $S$. hoyi is not surprising as there are more than 125 specimens held at the University of Alaska Museum of the North that were collected north of $65^{\circ} \mathrm{N}$ in Alaska, with the most northerly taken near the Dalton Highway at the Dietrich River $\left(67^{\circ} 37^{\prime} \mathrm{N}, 149^{\circ} 46.8^{\prime} \mathrm{W}\right.$; UAM 23050$)$. In 
addition, van Zyll de Jong (1983) reported specimens from Chick Lake and Fort Franklin, two locations north of $65^{\circ} \mathrm{N}$ in the Northwest Territories. It is likely that $S$. hoyi ranges further north in the Yukon; this is a species of the boreal forest and it likely extends north to the treeline. Further observations are needed to document the range of $S$. hoyi and other soricids in the Yukon and elsewhere in northwestern North America (Cook et al. 1997).

\section{Acknowledgments}

We thank Kevin Lake, Elise Bolduc, Kyle Russell, Kieran O'Donovan, Shannon Barker, Lea Randall, Brian Bell, Sara Nielsen, Michael Smith, Becky Cadsand and Matthias Clyde for able assistance in the field or lab. Funding for this work was provided by McGill University, the Yukon Department of Environment, and NatureServe Yukon. We thank Murray Humphries, Julie Frisch and Gordon McRae for logistical support while on the Dempster Highway.

\section{Literature Cited}

Cook, J. A., C. J. Conroy, and J. D. Herriges, Jr. 1997. Northern record of the water shrew, Sorex palustris, in Alaska. Canadian Field-Naturalist 111: 638-639.

Dokuchaev, N. E. 1997. A new species of shrew (Soricidae, Insectivora) from Alaska. Journal of Mammalogy 78: 811817.
Jarrell, G. H. 1986. A northern record of the water shrew, Sorex palustris, from the Klondike River, Yukon Territory. Canadian Field-Naturalist 100: 391.

Nagorsen, D. W. 1996. The mammals of British Columbia Volume 2: Opossums, shrews and moles of British Columbia. Royal BC Museum Handbook. UBC Press, Vancouver. 169 pages.

Nagorsen, D. W. 2002. An identification guide to the small mammals of British Columbia. Ministry of Sustainable Resource Management, Ministry of Water, Land, and Air Protection, Biodiversity Branch, and Royal BC Museum. 153 pages.

Nagorsen, D. W., and D. M. Jones. 1981. First records of the tundra shrew (Sorex tundrensis) in British Columbia. Canadian Field-Naturalist 95: 93-94.

Peirce, K. N., and J. M. Peirce. 2000. Range extensions for the Alaska tiny shrew and pygmy shrew in southwestern Alaska. Northwestern Naturalist 81: 67-68.

Prince, L. P. 1941. Water traps capture the Pygmy Shrew (Microsorex hoyi) in abundance. Canadian Field-Naturalist 55: 72.

van Zyll de Jong, C. G. 1983. Handbook of Canadian mammals. 1: Marsupials and insectivores. National Museums of Canada, Ottawa. 210 pages.

Youngman, P. M. 1975. Mammals of the Yukon Territory. National Museums of Canada, Ottawa, Ontario. Publications in Zoology 10: 1-192.

Received 25 January 2006

Accepted 15 January 2008 